\title{
PENINGKATAN MOTORIK HALUS DENGAN MEDIA KERTAS KOKORU PADA ANAK KELOMPOK A TK ABADI PERTIWI MARANGKAYU KABUPATEN KUTAI KARTANEGARA TAHUN AJARAN 2017/2018
}

\author{
Noviyana Syahril \\ PG PAUD FKIF Universitas Widya Gama Mahakam Samarinda \\ ( noviyanakhalid@Gmail.Com )
}

\begin{abstract}
ABSTRAC
Early-age children's physical development relates to the development of motor skill, which is defined as the ability to perform complex muscle-and-nerve acts that produce movement. To develop this skill, stimulation is needed. Responding this issue, the researcher conducted a classroom action research to enhance students' sensory motor skill by using kokoru paper as a media to stimulate the skill. Moreover, the researcher carried out the study in Abadi Pertiwi Kindergarten MarangkayuKabupatenKutaiKartanegara and involved fifteen students aged four to five as the research subjects. In addition, the gathered data was analyzed qualitatively. Based on the data analysis, it shows that in cycle I students' sensory motor skill increased $31.64 \%$. Considering the percentage which was below the indicator of success, so the researcher continued the treatment into cycle II. As the result, students improved their sensory motor skill into $94.44 \%$ in cycle II. Due the result of observation on four aspects of assessment and the percentage, it can be said that students have reached the expected minimum standard. To sum up, the usage of kokoru paper in learning activity is effective to improve students' sensory motor skill. As the consequences, teachers are expected to increase their teaching skill and motivate students so that students are involved actively in learning activitywith kokoru paper.
\end{abstract}

Key words: sensory motor skill, kokoru paper

\section{PENDAHULUAN}

Pendidikan anak usia dini merupakan bentuk penyelenggaraan pendidikan mengutamakan peletakan dasar ke arah pertumbuhan dan perkembangan fisik (koordinasi motorik halus dan kasar),kecerdasan,sosialemosional,bahasa dan komunikasi yang disesuaikan dengan tahap perkembangan anak usia dini (Santi,2009: XI).Masa anak usia dini (golden age) adalah masa yang paling tepat untuk mengoptimalkan semua aspek perkembangan yang dimiliki anak.Menurut Suyadi motorik halus yaitu meningkatnya gerak tubuh yang melibatkan otot dan syaraf yang jauh lebih kecil (2010:68-69). Owens (2008) memaparkan perkembangan motorik halus menjadi dasar dalam mengembangkan serta meningkatkan banyak keterampilan ketika masa anakanak.

Anak yang memiliki kesulitan dalam motorik halus akan mengalami frustasi karena tidak dapat melakukan tugas sehari-hari,seperti menggambar 
ataupun memotong dengan gunting. Pendidikan anak usia dini (PAUD) adalah jenjang sebelum pendidikan dasar yang merupakan suatu upaya pembinaan yang ditujukan bagi anak sejak lahir sampai usia 6 tahun. Menurut Slamet Suyanto ( $2005: 5$ ) anak usia dini sedang dalam proses pertumbuhan dan perkembangan paling pesat, baik fisik maupun mental. Pertumbuhan dan perkembangan anak telah dimulai sejak prenatal yaitu sejak dalam kandungan. Pembentukan sel saraf otak, sebagai modal pembentukan kecerdasan, terjadi saat anak dalam kandungan. Anak usia dini memiliki peran penting bagi perkembangan individu dan kehidupan berbangsa dan bernegara. Pada usia tersebut berbagai aspek perkembangan anak mengalami pertumbuhan dan perkembangan yang pesat. Oleh karena itu, pengembangan secara tepat di usia dini menjadi penentu bagi perkembangan individu pada masa selanjutnya.

Salah satu cara untuk meningkatkan kemampuan motorik halus anak dengan kegiatan kreasi kokoru, melalui media demonstrasi. dengan metode demonstrasi juga dapat meningkatkan imajinasi anak, karena yang disampaikan oleh guru lebih menarik, dapat mengundang perhatian anak, sehingga anak dapat mengasah kemampuan mereka. Anak diupayakan mampu membuat apa yang telah di demonstrasikan. dalam melaksanakan metode demontrasi dalam suasana gembira dan menyenangkan, sehingga anak termotivasi untuk memperhatikan sampai selesai dan mendapat pengalaman berharga.

Belajar adalah kewajiban untuk setiap orang. Belajar menjadikan orang terbuka cakrawalnya. Bertambah pengetahuan dan wawasan tentang dunia. Kebutuhan belajar sejak dini karena daya ingat anak masih murni dan belum tercampuri oleh sifat - sifat negative. Pertama ditekankan adalah bagaimana meningkatkan kemampuan anak. Dengan berkembangnya kualitas maka seorang anak akan mempunyai kemampuan baik kemampuan kreatif maupun inovatif. Tentunya hal ini terwujud jika diberikan ransangan secara maksimal. Usia 4 - 6 tahun merupakan usia peka dalam perkembangan aspek berfikir logis anak. Anak mulai sensitive untuk menerima berbagai upaya perkembangan kemampuan fisik motorik, kognitif, bahasa, social emosional.Dalam tubuh manusia terdapat syaraf yang bertugas menghantarkan ransangan influs dari syaraf pusat. Syaraf inilah yang memacu kualitas seorang anak. Jika syaraf ini terus dilatih dan dikembangkan tentunya kemampuan kualitas anak akan meningkat salah satunya dengan melipat menggunakan media kertas lipat. Kemampuan anak perlu dirangsang. 
Dimulai dari rumah, anak diberi kesempatan untuk mengembangkan kemampuan seluas - luasnya dengan berkarya lebih kreatif. Ditaman kanak kanak media kertas lipat merupakan salah satu alat pembelajaran yang digunakan untuk melatih motorik halus anak. Menurut Briggs ( 1970 ) yang dikutip ( Sadiman, 1986 : 6 ) berpendapat " Bahwa Media adalah segala alat fisik yang dapat menyajikan pesan serta merangsang siswa untuk belajar”. Dengan media kertas kokoru anak belajar melipat dan menggulung sebuah kertas dan melalui proses yang lama, sebelum akhirnya bisa menciptakan sebuah karya.

\section{METODE PENELITIAN}

\section{Jenis Penelitian}

Penelitian dalam melakukan penelitian ini menggunakan metode Penelitian Tindakan Kelas ( PTK) dalam bahasa inggris sering disebut Classroom Action Research ( Suharsimi Arikunto, 2006: 93). Penelitian tindakan adalah penelitian yang bukan menyangkut halhal statis, melainkan bentuk dinamis, yang menginginkan adanya perubahan kearah yang lebih baik dari suatu praktek pendidikan yang dilakukan guru dengan melakukan tindakan - tindakan dalam pembelajaran. Penelitian tindakan kelas menggunakan kolaboratif dan partisipatori ( participatory action research ) yaitu kegiatan penelitian yang dilakukan dengan melibatkan masyrakat agar merasa ikut serta memilki program kegiatan tersebut serta berniat ikut aktif memecahkan masalah berbasis masyrakat ( Suharsimi Arikunto 2006 : 95 ). Masyarakat yang dimaksud dalam penelititan ini adalah para guru kelas dan orangtua murid kelompok A TK Abadi Pertiwi.Penelitian tindakan ini bagian dari penelitian umum. PTK juga berguna guru untuk menguji suatu teori pembelajaran, apakah sesuai dengan kondisi kelas yang dihadapi atau tidak. Penelitian adalah suatu kegiatan penyelidikan yang dilakukan menurut metode ilmiah atau teknologi. Penelitian ini bertujuan untuk meningkatkan kemampuan motorik halus anak pada kelompok A TK. Abadi Pertiwi Kec. Marangkayu Kab. Kukar .

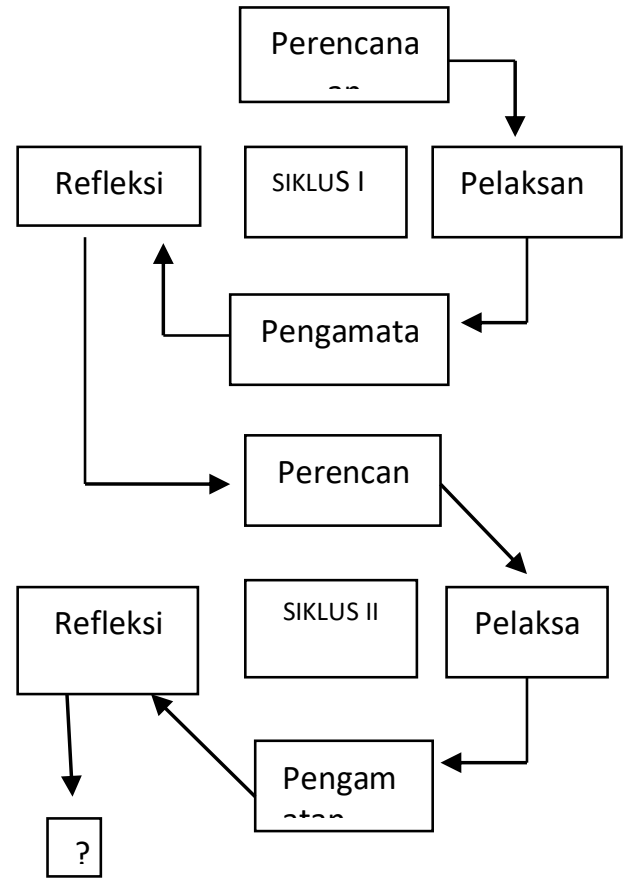

Gambar 1. Alur siklus

(Arikunto 2009: 105 ) 


\section{Subyek Penelitian}

Penelitian tindakan kelas ( PTK ) ini dilakukan di TK Abadi Pertiwi Jl. Mahkota Raja Dusun Suka Makmur Rt. 14 Desa Santan Ulu kecamatan Marangkayu. Penelitian ini bekerjasama dengan satu guru, sedangkan subyek penelitian diambil adalah Kelompok A. Waktu pelaksanaan Semester ITahun Ajaran 2017 / 2018.

\section{Instrumen Penelitian}

Obsevasi

Lembar obsevasi yang akan digunakan dalam peneltian ini adalah :

1. Lembar obsrevasi aktivitas guru, yang digunakan untuk mengamati kegiatan pembelajaran media kertas origami yang dilakukan oleh guru

2. Lembar observasi aktivitas siswa, yang digunakan untuk mengamati aktivitas siswa dalam kegiatan pembelajaran melipat kertas origami yang dilakukan oleh guru

Instrumen Penilaian Anak

Intrumen penilaian anakberupa penilaian angka sesuai indikator perkembangan anak yang meliputi BSB (berkembang sangat baik), BSH (berkembang sesuai harapan), MB (mulai berkembang), dan BB (belum berkembang).

\section{Prosedur Penelitian}

Penelitian tindakan kelas ini bersifat berdasarkan pada permasalahan yang muncul dalam pembelajaran Kreasi Kokoru . Penelitian tindakan kelas membuat guru dapat meneliti dan mengkaji sendiri kegiatan praktek pengajaran karena yang dihadapi adalah permasalahan aktual.

Menurut Arikunto ( 2006 : 97 ) Pelaksanaan penelitian tindakan kelas terdapat empat tahap yaitu :
a. Perencanaan
b. Pelaksanaan tindakan
c. Observasi
d. Refleksi

\section{Teknik Pengumpulan Data}

\section{Observasi untuk Anak}

Observasi untuk anak adalah pengumpulan data untuk mendapatkan informasi dengan cara pengamatan langsung terhadap sikap dan perilaku anak, kemampuan yang telah dicapai oleh anak, khususnya kemampuan menggunakan kertas kokoru.

\section{Observasi untuk Guru}

Observasi untuk guru adalah pengumpulan data untuk mengamati proses perkembangan pembelajaran yang dilakukanoleh guru dalam menyampaikan tentang kreasi kokoru, melalui demonstrasi penguasaan terhadap metode demonstrasi serta penguasaan guru dalam penerapan metode tersebut. Berlangsung diketahui pada saat berkreasi kokoru didepan kelas masih ada anak yang belum dapat menggunakan kokoru dengan benar.

Begitu juga pada saat proses mengerjakan tugas membentuk kreasi buah ceri ada anak yang belum dapat 
menggulung dengan benar. Ada anak dapat membuat satu gulungan, serta belum dapat mengikuti langkah-langkah dalam menggulung kertas, tidak mandiri dalam menggulung kertas dan anak rapi dalam melipat kertas.

\section{Dokumentasi}

Dokumentasi

adalah

pengumpulan data berupa photo yaitu menggambarkan apa yang sedang terjadi dikelas pada pembelajaran kreasi kertas kokoru, mencakup suasana kelas, peristiwa-peristiwa penting atau yang khusus terjadi berupa ilustrasi dari episode-episode, untuk membantu mendeskripsikan dilapangan.

\section{Teknik Analisis Data}

Data yang diperoleh melalui lembar kegiatan atau lembar evaluasi yang merupakan hasil yang disampaikan oleh guru kepada anak setiap pertemuan pembelajaran dalam setiap siklus.

Hasil ini sesuai dengan rencana pelaksanaan pembelajaran harian (RPPH) adapun pelaksanaan pembelajaran dalam peningkatan kemampuan motorik halus anak dengan media kertas kokoru melalui demonstrasi dikatakan berhasil jika pembelajaran itu tercapai nilai sangat baik $80 \%$ dari jumlah anak yang ada dikelas. Analisis ini dihitung dengan menggunakan statistic sederhana, Aqib (2009 : 115). Analisis ini akan dihitung dengan menggunakan statistik sederhana,yaitu sebagai berikut :
1. Penilaian Rata - rata

Penilaian ini dilakukan dengan cara menjumlahkan nilai yang diperoleh anak kemudian dibagi dengan jumlah anak, sehingga dapat diperoleh nilai rata - rata menggunakan rumus sebagai berikut:

$\overline{\mathrm{X}}=\frac{\sum \mathrm{X}}{\sum \mathrm{N}}$

Keterangan

$\mathrm{X}=$ niTai rata - rata

$\sum \mathrm{X} \quad=$ jumlah rata - rata

$\sum \mathrm{N} \quad=$ jumlah anak

2. Penilaian untuk ketuntasan belajar Anak dikatakan berhasil dalam meningkatkan kemampuan motorik halus anak dalam berkreasi kokoru, jika anak memenuhi ketuntasan belajar, yaitu masuk dalam katergori 3 ( $\mathrm{BSH}$ ) dan 4 (BSB). Untuk mencapai presentase ketuntasan belajar digunakan rumus sebagai berikut :

Rumus :

$$
X=\frac{\text { Skor Perolehan }}{\text { Skor Maximum }} \times 100
$$

Jika Skor Minimum bukan Nol maka rumus $N=\frac{\text { Skor Perolehan }- \text { Skor Minimum }}{100} X$

\section{Kriteria Keberhasilan}

Kriteria keberhasilan penelitian dinyatakan berhasil minimal $75 \%$ jumlah anak memperoleh kriteria nilai adalah BSB dan BSH.

Tabel . Kriteria Penilaian Tingkat Keberhasilan Belajar Anak 


\begin{tabular}{|c|c|c|}
\hline No & $\begin{array}{c}\text { Tingkat } \\
\text { Keberhasilan }\end{array}$ & Kriteria \\
\hline 1 & $85-100 \%$ & Sangat Baik \\
2 & $70-84 \%$ & Baik \\
3 & $56-69 \%$ & Cukup \\
4 & $41-55 \%$ & Kurang \\
5 & $0-40 \%$ & Kurang Sekali \\
\hline \multicolumn{3}{|c|}{ Sumber : Arikunto 2009 }
\end{tabular}

\section{Indikator Penilaian}

Adapun Indikator Penilaian yang digunakan adalah sebagai berikut :

1. Keaktifan anak dalam melaksanakan kegiatan

2. Mengkoordinasikan mata dan tangan anak dalam menggulung kertas kokoru

3. Kerapian anak dalam menggulung kertas kokoru

4. Melakukan gerakan manipulatif untuk menghasilkan bentuk dengan media kertas kokoru

\section{HASIL PENELITIAN DAN}

\section{PEMBAHASAN}

\section{HASIL PENELITIAN}

Pelaksanaan penelitian tindakan kelas pada anak TK Abadi Pertiwi Marangkayu dilaksanakan dalam 2 siklus yaitu siklus I, siklus II. Pada setiap pelaksanaan tindakan siklus penelitian terdiri dari 4 tahapan yaitu, perencanaan,pelaksanaan,obsrevasi dan refleksi.

\section{Siklus I}

Jadi, hasil observasi dari tiap aspek penilaian pada siklus I pertemuan III di TK Abadi Pertiwi pada anak kelompok A dengan jumlah murid 15 anak. Pada aspek penilaian keaktifan anak dalam melaksanakan kegiatan menggulung kertas ada 10 anak atau $66.67 \%$, pada aspek mengkoordinasikan mata dan tangan anak dalam menggulung kertas ada 10 anak atau $66.67 \%$, pada aspek kerapian anak dalam menggulung kertas ada 12 anak atau $80 \%$, pada aspek melakukan gerakan manipulatif untuk menghasilkan bentuk media dengan media kertas kokoru ada 10 anak atau $66.67 \%$. mendapat nilai BSH (Berkembang SesuaiHarapan). namun, belum ada anak yang mencapai nilai BSB ( Berkembang Sangat Baik ) pada Siklus I pertemuan III ini.

Tabel 1. Rekapitulasi Data Kemampuan Motorik Halus Anak Pada Siklus I

\begin{tabular}{|c|c|c|c|c|c|}
\hline $\begin{array}{l}\mathrm{N} \\
\mathrm{o}\end{array}$ & Aspek Penilaian & P I & P II & $\begin{array}{c}\mathrm{P} \\
\mathrm{III}\end{array}$ & NR \\
\hline 1 & $\begin{array}{l}\text { Keaktifan anak } \\
\text { dalam } \\
\text { menggulung } \\
\text { kertas }\end{array}$ & $\begin{array}{l}13 \\
33\end{array}$ & $\begin{array}{l}26 \\
67\end{array}$ & $\begin{array}{l}66, \\
67\end{array}$ & $\begin{array}{c}35,5 \\
5\end{array}$ \\
\hline 2 & $\begin{array}{l}\text { Mengkoordinasik } \\
\text { an mata dan } \\
\text { tangan anak } \\
\text { dalam } \\
\text { menggulung } \\
\text { kertas }\end{array}$ & 0 & $\begin{array}{c}6,6 \\
7\end{array}$ & $\begin{array}{l}66, \\
67\end{array}$ & $\begin{array}{c}24,4 \\
4\end{array}$ \\
\hline 3 & $\begin{array}{l}\text { Kerapian anak } \\
\text { dalam } \\
\text { menggulung } \\
\text { kertas }\end{array}$ & $\begin{array}{c}6,6 \\
7\end{array}$ & 40 & 80 & $\begin{array}{c}42,2 \\
2\end{array}$ \\
\hline 4 & $\begin{array}{l}\text { Melakukan } \\
\text { gerakan } \\
\text { manipulatif } \\
\text { untuk } \\
\text { menghasilkan } \\
\text { bentuk }\end{array}$ & $\begin{array}{c}6,6 \\
7\end{array}$ & 0 & $\begin{array}{l}66, \\
47\end{array}$ & $\begin{array}{c}24,3 \\
8\end{array}$ \\
\hline & Jumlah & $\begin{array}{c}6,6 \\
7\end{array}$ & $\begin{array}{l}18, \\
33\end{array}$ & $\begin{array}{l}69, \\
95\end{array}$ & $\begin{array}{c}31,6 \\
4\end{array}$ \\
\hline
\end{tabular}

Berdasarkan tabel diatas maka nilai rata - rata yang diperoleh untuk siklus I pertemuan I jumlah rata-rata $6,67 \%$, pertemuan II jumlah rata-rata yaitu 18,33 dan pertemuan III jumlah 
rata-rata yaitu 69,95 dan masih perlu ditingkatkan pada silkus II

Data yang diperoleh melalui pengamatan dijadikan sebagai pedoman oleh peneliti dan guru untuk menentukan refleksi pada permasalahan yang muncul sehingga dapat mencari solusi terbaik untuk mengatasi permasalahan tersebut.Pemberian solusi tersebut bertujuan untuk meningkatkan kemampuan motorik halus anak kelompok A melalui kegiatan Kreasi menggulung kertas kokoru / kerdus serta merencanakan tindakan yang akan dilaksanakanpada siklus selanjutnya.

Berikut ini terdapat beberapa evaluasi dari pelaksanaan siklus I yang perlu dicari solusinya serta perlu adanya perbaikan untuk peningkatan pada siklus selanjutnya

a. Kertas Kokoru yang digunakan perlu ditambah agar anak tetap antusias ketika kegiatan menggulung kertas menggunakan kerdus banyak anak cenderung kurang bersemangat karena warnanya yang kurang menarik.

b. b.Terdapat beberapa anak yang mengalami penurunan ke Siklus I ketika pelaksanaan kegiatan menggulung kertas menggunakan kerdus.

c. Pada siklus ini anak masih mencapai kategori BSH dengan jumlah nilai rata-rata 31,64 maka masih perlu peningkatan pada siklus berikutnya

Dari beberapa evaluasi diatas, maka peneliti dan guru berdiskusi untuk mencari solusi agar kegiatan pembelajaran pada siklus berikutnya dapat berjalan lancar dan dapat meningkatkan kemampuan motoirk halus anak melalui kegiatan menggulung kertas. Solusi dari kendala tersebut adalah :

a) Penambahan kertas kokoru / kedus berwarna untuk kegiatan menggulung kertas sangat perlu dilakukan agar anak tidakmerasa bosan.

b) Berdasarkan permasalahan diatas maka peneliti dan guru memutuskan bahwa pada Siklus II sebaiknya kegiatan menggulung kertas lebih bervariasi agar anak dapat lebih kreatif dalam mengkreasikan kertas kokoru sesuai imajinasinya.

\section{Siklus II}

Hasil observasi dari tiap aspek penilaian pada siklus II pertemuan III di TK Abadi Pertiwi pada anak kelompok A dengan jumlah murid 15 anak. Pada aspek penilaian keaktifan anak dalam melaksanakan kegiatan menggulung kertas ada 3 anak atau 20\%, pada aspek mengkoordinasikan mata dan tangan anak dalam menggulung kertas ada 5 anak atau 33,33\%, pada aspek kerapian anak dalam menggulung kertas ada 1 
anak atau $6,67 \%$, pada aspek melakukan gerakan manipulatif untuk menghasilkan bentuk dengan media kertas kokoru ada 2 anak atau 13,33\%. mendapat nilai BSH (Berkembang SesuaiHarapan). Anak yang mencapai nilai BSB ( Berkembang Sangat Baik ) pada aspek penilaian keaktifan anak dalam melaksanakan kegiatan menggulung kertas ada 12 anak atau $80 \%$, pada aspek mengkoordinasikan mata dan tangan anak ada 10 atau 66,67\%,pada aspek kerapian anak dalam menggulung kertas 14 anak atau 93,33\%,pada aspek melakukan gerakan manipulatif untuk menghasilkan bentuk dengan media kertas kokoru ada 13 anak atau 86,67\%.

Tabel 2. Rekapitulasi Data Kemampuan Motorik Halus Anak Pada Siklus II

\begin{tabular}{|c|c|c|c|c|c|}
\hline No & Aspek Penilaian & P I & P II & P III & NR \\
\hline 1 & $\begin{array}{l}\text { Keaktifan anak } \\
\text { dalam } \\
\text { menggulung } \\
\text { kertas }\end{array}$ & $\begin{array}{l}93, \\
33\end{array}$ & 93,33 & 100 & $\begin{array}{c}95, \\
55\end{array}$ \\
\hline 2 & $\begin{array}{l}\text { Mengkoordinasi } \\
\text { kan mata dan } \\
\text { tangan anak } \\
\text { dalam } \\
\text { menggulung } \\
\text { kertas } \\
\end{array}$ & $\begin{array}{l}86, \\
67\end{array}$ & 100 & 100 & $\begin{array}{c}95, \\
55\end{array}$ \\
\hline 3 & $\begin{array}{l}\text { Kerapian anak } \\
\text { dalam } \\
\text { menggulung } \\
\text { kertas }\end{array}$ & $\begin{array}{c}10 \\
0\end{array}$ & 86,67 & 100 & $\begin{array}{c}95, \\
55\end{array}$ \\
\hline 4 & $\begin{array}{l}\text { Melakukan } \\
\text { gerakan } \\
\text { manipulatif } \\
\text { untuk } \\
\text { menghasilkan } \\
\text { bentuk }\end{array}$ & 80 & 93,34 & 100 & $\begin{array}{c}91, \\
11\end{array}$ \\
\hline & Jumlah & 90 & 93,33 & 100 & $\begin{array}{l}94, \\
44\end{array}$ \\
\hline
\end{tabular}

Berdasarkan tabel diatas maka nilai rata - rata yang diperoleh untuk siklus I pertemuan I jumlah rata-rata $90 \%$, pertemuan II jumlah rata-rata yaitu 93,33 dan pertemuan III jumlah rata-rata yaitu 100\%. Maka penelitian ini dihentikan oleh peneliti karena sudah mencapai nilai ketuntasan.

Evaluasi yang dilaksanakan tindakan yang dilakukan pada siklus I berhasil diterapkan pada pelaksanaan siklus II adapun hasilnya sebagai berikut

1. Penggunaan kertas kokoru pada siklus II berhasil meningkatkan antusiasme anak untuk melaksanakan kegaitan menggulung kertas

2. Upaya yang dilakukan untuk kegaitan menggulung kertas menggunakan kertas kokoru pada siklus II sangat efektif dilakukan karena pada pelaksanaan siklus II anak-anak selesai melakukan kegiatan menggulung kertas dengan tepat waktu dan tidak melebihi alokasi waktu yang disediakan. Sealain itu, penilaian perkembangan motorik halus anak juga lebih detail dan mudah dilakukan.

Peningakatan kemampuan motorik halus melalui kegiatan menggulung kertas pada kelompok A TK Abadi Pertiwi kecamatan Marangkayu pada pra tindakan, siklus I dan siklus II diketahui dengan cara melihat perolehan persentase kemampuan motorik halus anak dan sesudah dilakukan tindakan pada siklus I dan siklus II. Rata-rata persentase kemampuan motorik halus anak 
kelompok A TK Abadi Pertiwi kecamatan Marangkayu pada pelaksanaan siklus I dan peningkatan signifikan terjadi pada siklus II.

Berdasarkan diatas dapat disimpulkan bahwa kemampuan motorik halus melalui menggulung kertas yang dilaksanakan pada siklus II sudah mencapai indikator keberhasilan yang dilakukan oleh peneliti yaitu $85.55 \%$. Berdasarkan hasil refleksi, maka peneliti dan guru menghentikan tindakan pembelajaran untuk menigkatkan kemampuan motorik halus melalui kegiatan menggulung kertas pada kelompok A TK Abadi Pertiwi kecamatan Marangkayu karena sudah mencapai indikator keberhasilan yang telah direncanakan oleh peneliti yaitu mencapai kriteria $75 \%$ keatas.kategori MB 7.22\%, kategori BSH $68.89 \%$ dan kategori BSB adalah $16.67 \%$. Untuk mendapatkan nilai ketuntasan maka nilai rata- rata $\mathrm{BSH}$ ditambah $\mathrm{BSB}$ dengan nilai rata- rata BSB mendapat $85.55 \%$. Maka penelitian ini dihentikan oleh peneliti karena sudah mencapai nilai ketuntasan belajar.

PEMBAHASAN

Penelitian tindakan yang dilakukan untuk meningkatkan kemampuan motorik halus anak melalui kegiatan menggulung kertas telah dilaksanakan di kelompok A TK Abadi Pertiwi selama 2 siklus menunjukkan adanya peningkatan serta keberhasilan.
Berikut ini merupakan rata-rata presentase kemampuan motorik halus anak pelaksanaan siklus I dan siklus II.

Tabel 3. Hasil Perbandingan Antar Siklus

\begin{tabular}{|c|l|c|c|}
\hline No & Indikator Penilaian & $\begin{array}{c}\text { Siklus I } \\
(\%)\end{array}$ & $\begin{array}{c}\text { Siklus II } \\
(\%)\end{array}$ \\
\hline 1 & $\begin{array}{l}\text { Keaktifan anak } \\
\text { dalam } \\
\text { melaksanakan } \\
\text { kegiatan } \\
\text { menggulung kertas }\end{array}$ & 35,55 & 95,55 \\
\hline 2 & $\begin{array}{l}\text { Mengkoordinasikan } \\
\text { mata dan tangan } \\
\text { anak dalam } \\
\text { menggulung kertas } \\
\text { kokoru }\end{array}$ & 24,44 & 95,55 \\
\hline 3 & $\begin{array}{l}\text { Kerapian anak } \\
\text { dalam menggulung } \\
\text { kertas }\end{array}$ & 42,22 & 95,55 \\
\hline 4 & $\begin{array}{l}\text { Melakukan gerakan } \\
\text { manipulatif untuk } \\
\text { menghasilkan } \\
\text { bentuk dengan } \\
\text { media kertas } \\
\text { kokoru }\end{array}$ & 24,38 & 91,11 \\
\hline & \multicolumn{1}{|c|}{ Jumlah } & 31,64 & 94,44 \\
\hline
\end{tabular}

Berdasarkan tabel 4.11 di atas dapat diketahui adanya peningkatan dari data yang diperoleh pada siklus I dan siklus II. Persentase kemampuan motorik halus anak kelompok A TK Abadi Pertiwi pada Siklus I 31.64\% dan terjadi peningkatan signifikan pada pelaksanaan tindakan Siklus II menjadi $94,44 \%$, sehingga antara siklus I dan II terjadi peningkatan sebesar $62,8 \%$.

Berdasarkan analisis yang dilakukan oleh peneliti kemampuan motorik halus anak mengalami peningkatan setelah pelaksanaan kegiatan menggulung kertas dilakukan menggunakan kertas kokoru dan kegiatan menggulung kertas jarang dilakukan di TK Abadi Pertiwi sehingga 
menimbulkan antusiasme yang tinggi dari anak dan stimulasi yang diberikan kepada anak dapat dilakukan secara maksimal karena stimulasi motorik halus yang diberikan menggunakan beberapa variasi.

Kegiatan menggulung kertas pada siklus I menggunakan 2 alat yang berbeda yaitu kertas kokoru dan kerdus hasilnya banyak anak yang mengalami kesulitan serta mengalami penurunan persentase. Kegiatan menggulung kertas pada siklus II dilakukan menggunakan 1 alat saja yaitu kertas kokoru hasilnya kemampuan motorik halus anak dalam keaktifan anak dalam melaksanakan kegiatan menggulung kertas, mengkoordinasikan mata dan tangan anak dalam menggulung, kerapian anak dalam menggulung kertas, melakukan gerakan manipulatif untuk menghasilkan bentuk dengan media kertas kokoru dapat berkembang sangat baik dan sesuai indikator keberhasilan yang ditetapkan.

Kemampuan motorik halus anak ketika siklus I memasuki kriteria MB atau $31,64 \%$ tetapi pada siklus II dapat kembali mencapai kriteria BSB atau 94,44\%. Hal tersebut disebabkan karena kemampuan motorik halus anak dalam mennggulung kertas menggunakan kertas kokoru dan kerdus mengalami penurunan dan mengalami peningkatan kembali ketika pelaksanaan siklus II kegiatan menggulung kertas dilakukan menggunakan kertas kokoru saja. Hal tersebut menunjukkan bahwa kemampuan anak dalam menerima hal yang baru memerlukan waktu yang lebih lama, tetapi ketika fokus pada 1 kegiatan yang sama anak cepat untuk menerima stimulasi yang diberikan.

Berdasarkan pernyataan diatas dapat disimpulkan bahwa kemampuan motorik halus setiap anak untuk mencapai kemampuan motorik halus yang maksimal dengan kriteria Berkembang Sangat Baik ( BSB) berbeda-berbeda sesuai dengan tahap perkembangannya sehingga pada hasil pengamatan yang dilakukan pada siklus I dan siklus II setiap hasil yang dicapai oleh anak juga berbeda-beda. Hal tersebut sesuai dengan teori perkembangan anak Sumantri ( 2005: 148) yang menyatakan bahwa perkembangan dan pembelajaran memperhatikan perbedaan individual setiap anak-anak yang berbeda-beda. Oleh karena itu tidak adil apabila menyamakan kemampuan anak dalam menerima stimulasi yang diberikan.

Indikator keberhasilan yang tercapai serta peningkatan persentase yang terjadi dari siklus I dan dilanjutkan pada siklus II dikarenakan kegiatan menggulung kertas dilakukan selama 6 kali pertemuan dimulai dari kegiatan menggulung kertas yang mudah ke sulit. Selain itu, kegiatan menggulung dilaksanakan secara berulang-ulang 
untuk mencapai hasil yang maksimal dan disesuaikan dengan perkembangan anak. Hal tersebut sesuai pendapat Dirjen Manajemen Pendidikan Dasar dan Menengah ( 2007 : 11 ) yang menyatakan bahwa perkembangan motorik halus dilakukan secara bertahap serta berulang - ulang sesuai kemampuan anak.

\section{PENUTUP}

\section{Kesimpulan}

1. Diketahui bahwa hasil persentase keberhasilan dengan kriteria berkembang sangat baik (BSB) pada kegiatan menggulung kertas kokoruanak mencapai $94,44 \%$ atau 14 dari 15 anak. Perbaikan yang dilakukan terhadap kendala yang muncul pada siklus I, menghasilkan peningkatan yang signifikan terhadapkemampuan menggulung kertas kokoru yang di capai anak kelompok A pada siklus II. Hal ini ditunjukan dari hasil yang dicapai dengan tingkat rata-rata ketuntasan meningkat menjadi $94,44 \%$ dari siklus I yaitu $31,64 \%$.

2. Pembelajaran melalui media kertas kokoru dapat meningkatkan kemampuan metorik halus pada kelompok A di TK. Abadi Pertiwi Tahun Ajaran 2017/2018. Oleh karena itu dianjurkan kepada guru Pendidikan Anak Usia Dini untukmenggunakan media kertas kokoru dan kerdus

3. dalam meningkatkan kemampuan Motorik halus dan kreatifitas anak Pendidikan Usia Dini.

\section{Saran}

1. Bagi anak,

Agar memiliki kemampuan berkreasi dengan baik, anak lebih muda membedakan warna, anak mampu mengelompokan warna dan bentuk.

2. Bagi guru,

Agar dapat menggunakan media pembelajaran dengan bantuan menggulung kertas untuk meningkatkan kemampuan kreasi anak usia dini, membimbing atau memotifasi kepada anak baik secara individual atau kelompok dilaksanakan dengan penuh kesabaran, kreatifitas guru dalam mengebangkan APE sebagai media pembelajaran perlu di tingkatkan dari waktu ke waktu.

3. Bagi lembaga TK,

Diharapkan kepada kepala sekolah agar dapat memberikan dukungan kepada guru untuk menggunakan media kertas kokoru dalam meningkatkan kreatifitas dan motorik halus anak didik.

4. Bagi orang tua,

Menstimulasi anak terhadap kemampuan kreatifitas anak yang dapat di mulai dari pengalaman 
anak sehari-hari dirumah

dilaksanakan dengan suasana yang menyenangkan, menindak lanjut kegiatan di sekolah menuju kegiatan anak di rumah.

\section{DAFTAR PUSTAKA}

Aqib, Zainal. 2009. Belajar dan pembelajaran di taman kanak-kanak. Yrama Widya : Bandung.

Aqib, Zainal. 2009. Penelitian Tindakan Kelas. Yrama Widya : Bandung.

Arikunto, Suharsimi. 2006. Prosedur Penelitian Suatu Pendekatan Praktik. PT. Rineka Cipta : Jakarta

Anonim. 2007. Departemen Pendidikan Dasar dan Menegah Direktorat Pembinaan Taman kanak-kanak dan Sekolah Dasar. Pedoman Pengembangan Fisik Motorik di Taman Kanak-kanak : Jakarta

Anoim . 2007. Dirjen Manajemen Pendidikan Dasar Dan Menengah.

Depertemen Pendidikn Nasional. 2007. Pedoman Pembelajaran Bidang Pengembangan Fisik Motorik di Taman Kanak-kanak. Drijen Manajemen Pendidikan Dasar dan menengah.
Endah. 2017. Perkembangan motorik Kasar dan Motorik Halus. Http : Pembelajaranguru.workpress.com/20 08/05/25/perkembangan Motorik kasar dan perkembangan motorik halus.

Hirai. 2009. Origami Untuk Sekolah Dasar. PT. Kawan Pustaka : Jakarta

MS. Sumantiri. 2005. Pengembangan Keterampilan Motorik Anak Usia Dini. Dinas Pendidikan : Jakarta.

Nuraini. 2009. Konsep Dasar Pendidikan Anak Usia Dini. PT. Indeks : Jakarta.

Noorlaila. 2010. Penduan Lengkap mengajar PAUD. Penerbit Pinusn(KKP) : Yogyakarta.

2009. Peraturan Mentri Pendidikan Nasional N0. 58 tentang Standar Pendidikan Nasional Anak Usia Dini. Depertemen Pendidikan Nasional : Jakarta.

Suyanto, Slamaet. 2005. Proses Perkembangan Anak Usia Dini. Jakarta

Suharsimi Dkk. 2009. Penelitian Tindakan Kelas. Bumi : Jakarta

Reno, Suryani. 2014. Kokoru untuk anak. Artcitra : Yogyakarta. 